\title{
顔面㾏攣症例に於忷る聴覚，平衡系の機能異常の検討
}

\author{
大橋 直樹・安村佐都紀・中川 肇 \\ 水越 鉄理・久世 照五*
}

\section{Abnormal Findings in Otoneurological Examinations in Patients with Hemifacial Spasm}

\author{
Naoki Ohashi, Satsuki Yasumura, Hajime Nakagawa, \\ Kanemasa Mizukoshi and Shougo Kuze \\ (Toyama Medical and Pharmaceutical University)
}

\begin{abstract}
Twenty four patients with hemifacial spasm underwent thorough examinations consisting of 1). taking subjective symptons (tinnitus and/or dizziness), 2). the otoneurological examinations (auditory and equilibrium examinations) and 3). checking the serum lipids. $\mathrm{X}$-rays (air CT and/or VAG) were taken in some cases. Abnormal findings were obtained in 6 patients in the auditory and in 17 patients in equilibrium examinations. Moreover, abnormal findings suggesting brain-stem disorders (elongation of I-V latency in bilateral sides, indefinite $\mathrm{V}$ peak in the healthy side, abnormal findings in the oculomotor system (saccadic or ataxic pursuit patterns, diminution or inversion in the horizontal OKN) were obtained in 11 patients. In 3 of them, the enlarged vertebral or basilar arteries were found by X-ray examination. In 3 of them, serum lipids (cholesterol or trigyceride) were high. One of them is medicated for hypertension. Therefore, we conclude that the abnormal otoneurological findings suggesting brain-stem disorders came from [1] brain-stem compression by enlarged vertebral or basilar arteries or [2] arteriosclerosis or hypertensive angiopathy in the brainstem.
\end{abstract}

Key words: hemifacial spasm, otoneurological examinations, equilibrium disturbance

はじめに

顔面疰攣は椎骨脳底動脈系の血管が loop を 形成し，いわゆる nerve〜vascular cross compression が第VII脳神経に cross talk を生じさせ ていることが原因として重要視されている．こ のために, 治療としては脳外科による MVD (micro vascular decompression 神経血管減圧 術）が第一選択とされている，ところで第壮脳 神経にも同様の病態から耳鳴, めまい等が生じ
ているとする報告1) もある。一方，いわゆる transitional zone が第UII脳神経と第UII脳神経と で異なっているために顔面痙攣症例には第UII脳 神経障害の合併は有り得ないとする報告2) もあ る。そこで，私達は顔面㾏攣症例について神経 耳科学的検査を行い第叫脳神経症状について検 討したのでその大要を報告する.

\section{症例と方法}

1987年 4 月から1989年 4 月まで，富山医科薬 
科大学耳鼻咽喉科で, 神経耳科学的検査を受け た顔面痸攣症例は総数24例であり，男性11女性 13であった．罹患側は右側12例左側12例と左右 差はなかった．年齢分布は図 1 に示すよらに50 才代に peak が認められた. 全例に対して病歴 の聴取, 純音聴力検查, $\mathrm{ABR}$, および平衡機 能検査を行った。な掞これらの神経耳科学的検 査の方法, 判定等については教室のシステムに 従って記録，分析した ${ }^{3)}$. また可能な症例にた いしては air CT, VAG などの画像検査も追加 した。

\section{結＼cjkstart果}

(1) 自覚症状 :

病歴では拍動性耳鳴が 3 例, めまいが 6 例に 認められた。めまいの訴兑のあった 6 例の内 2 例に回転性めまいが認められた，重複例を除く と病歴の聴取可能であった 23 例中 8 例の何かし らの聴覚平衡障害を示唆する症状が認められた.

(2) 聴覚所見 :

聴覚検査では $30 \mathrm{~dB}$ 以上の感音難聴が 4 例に, $\mathrm{ABR}$ の異常が 3 例に認められた. ABR の異 常例は両側の I-V 波間潜時延長が 2 例に健側 の V 波不明瞭が 1 例に認められた。

(3) 平衡機能検査 :

平衡機能検査は $\mathrm{ENG}$ 記録でュンピューター 分析しているが, 自発眼振 9 例, 頭位眼振 10 例, 頸部圧迫（捻転）眼振が12例で認められた。前 庭系検查では $\mathrm{CP}$ が 4 例, 両側前庭機能低下 1 例，FS（温度眼振の固視効果）の障害が 2 例
にそれぞれ認められた。眼球運動系検査では ETT で 4 例, 水平系 $\mathrm{OKN}$ で 3 例の異常が認 められた（表1）。

(4) 画像診断:

15例に CT, air CT または VAG の画像診断

表 1 顔面痤攣24症例の神経耳科学的所見

(1) 自覚症状 8 例 (23例中) 拍動性耳鳴 3 例 (21例中) めま 、 6 例 (23例中) （回転性 2 例）

(2) 聴覚検査の異常 6 例（24例中）

$\begin{array}{ll}30 \mathrm{~dB} \text { 以上の感音難聴 } & 4 \text { 例 } \\ \mathrm{ABR} \text { 異常 } & 3 \text { 例 } \\ \text { (両側 } \mathrm{I}-\mathrm{V} \text { 波間潜時延長 } & 2 \text { 例) } \\ \text { (健側 } \mathrm{V} \text { 波不明瞭 } & 1 \text { 例) }\end{array}$

（3) 平衡機能検査の異常 17例（24例中）

1 : 自発眼振 9 例, 頭位眼振 10 例 頚部圧迫（捻転） 12例

2 : 前庭系異常

DP

3 例

$\mathrm{CP}$

4 例

（患側 2，健側 2)

両側前庭機能低下 1 例 FFS (+) 2 例

3 : 眼運動系異常

ETT

4 例

$\mathrm{OKN}$

3 例

（解発不良 2 , 錯倒 1 )

年代別定国数

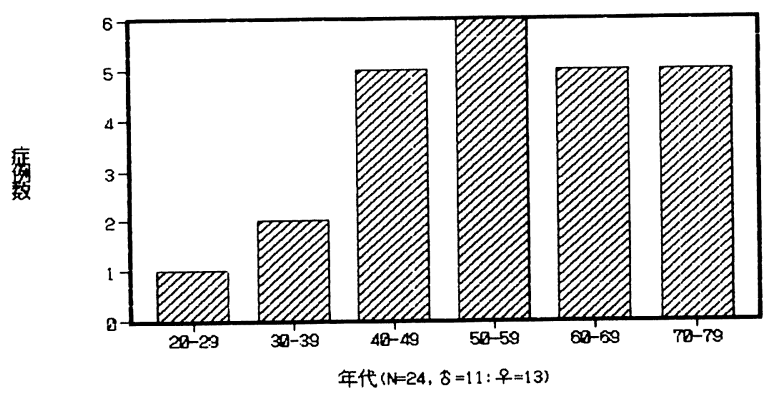

図 1 顔面痙戀症例の年代別症例数を示す 
が行われ, 異常血管陰影が認められたのは 5 例 であった。

(5) 血液所見 :
I血清脂質が 14 症例に検查され総 cholesterol，または TG 值が 5 例 (36\%) に異常高値を 示した。

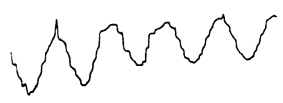

SACCADIC PURSUIT

$\left(0.3 \mathrm{~Hz}\right.$ AMP $\left.10^{\circ}\right)$
10 SEC

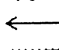

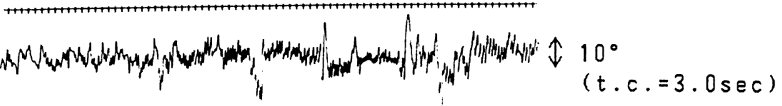

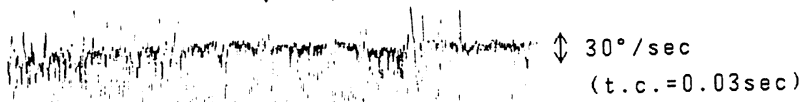

FFS $(+)\left(\right.$ 右 $\left.24^{\circ} \mathrm{C}\right)$

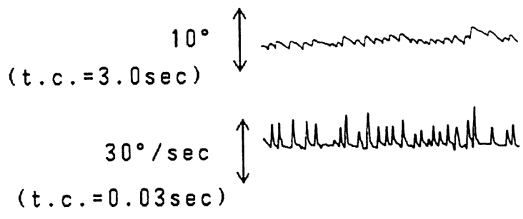

右向き自発眼振
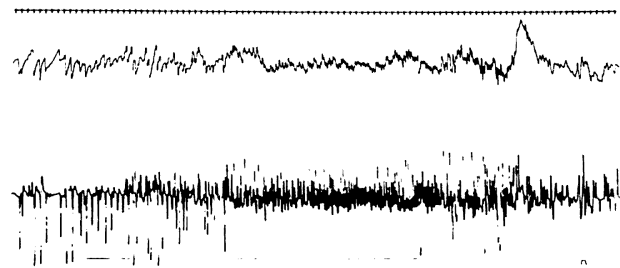

錯到を示したOKN

64歳 男性）の ENG 所見

\section{AIR CALORIC TEST \\ 10 SEC
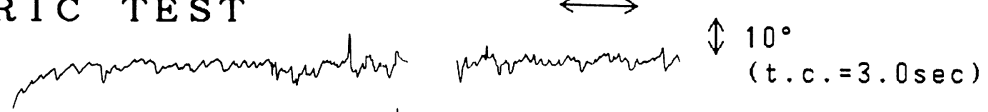

右 $24^{\circ} \mathrm{C}$

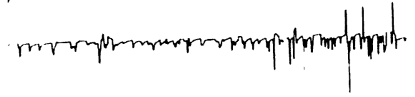

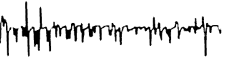

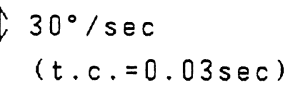

右 $50^{\circ} \mathrm{C}$
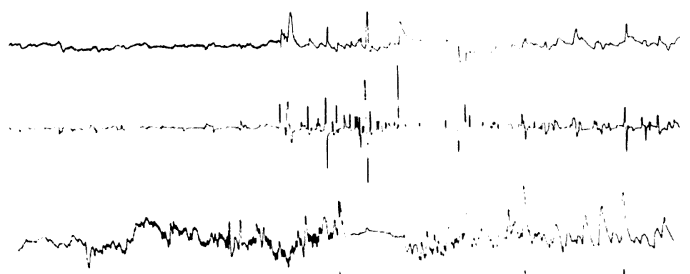

左 $24^{\circ} \mathrm{C}$
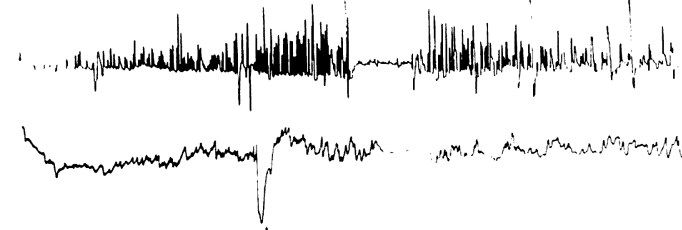

左 $50^{\circ} \mathrm{C}$

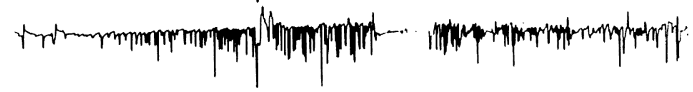


(6) 典型例 :

\section{症例 2}

64才の男性で罹病期間10年の眼瞼痤攣も伴っ た症例である.図 2 に示すよらに右向き自発眼 振が認められ，滑動性眼球運動は saccadic pursuit pattern を示した.ささらに air caloric test では右冷刺激, 左温刺激で固視による温度眼振 の抑制が久如していた. OKN では clockwise で刺激開始約 30 秒後から眼振の方向が逆転し一 側性の錯倒を示した。この症例には CT が施行 されたが特別な異常は示されなかった。しかし 総コレステロール值は $220 \mathrm{mg} / \mathrm{dl}$ と正常限界を 超えていた。

\section{症例 3}

40才の男性で左の顔面痤攣症例であるが図 3 に示すよらに air caloric test で，右の反応低下 が認められた。この症例では TG（中性脂肪）
が $289 \mathrm{mg} / \mathrm{dl}$ と高值をしめした.

\section{症例 7}

72才の男性で左の顔面疰攣症例である. 4 $\mathrm{KHz}$, click, $100 \mathrm{~dB}$ での ABR は患側である左 側では I-V 波間潜時はほぼ正常であったが， 健側である右側ではV 波は不明膫であった（図 4 )。滑動性眼球運動検査では図 5 のように ataxic pursuit pattern を示した。この症例では air CT が施行されており，患側（左側）の椎 骨動脈の拡張蛇行と第VII，第比脳神経を脳幹に
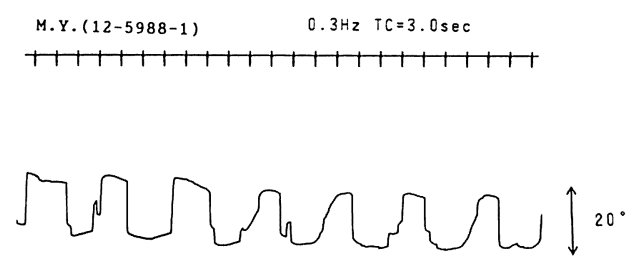

図 5 症例 7
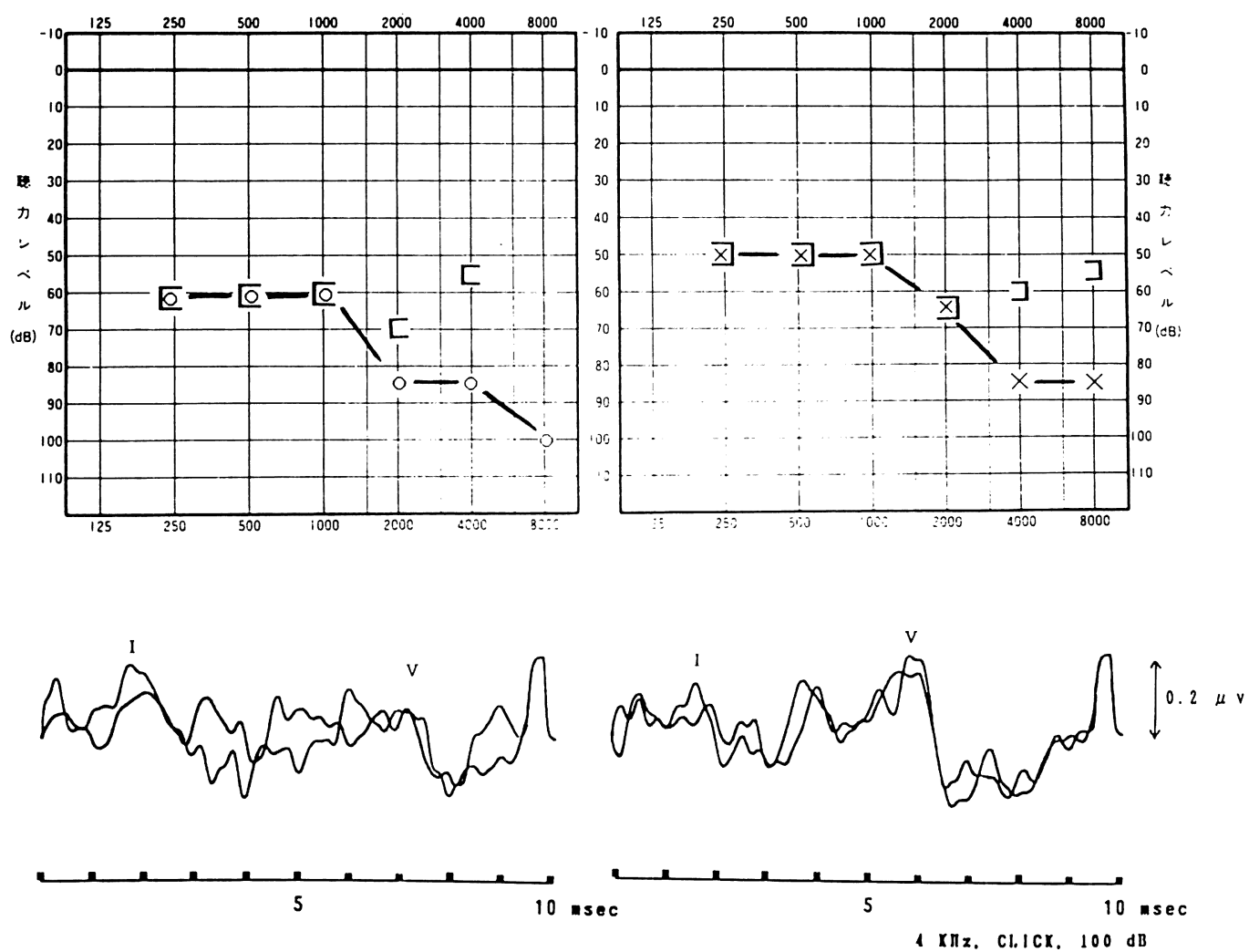

図 4 症例 7

72 歳 男性）の聴力所見 
近い部分で接触しているPICA と思われる小血 管が認められた（図 6 ).

これらの所見をむとめると臨床的な特徴とし て $1: \mathrm{ABR}$ の両側の異常, $2: \mathrm{ABR}$ の健側の 異常, 3 : 温度眼振の健側 $\mathrm{CP}, 4$ : 両側前庭機 能低下， 5 : 眼球運動の異常, $6:$ 温度眼振の固 視抑制の障害などが認められた症例が11例に及 んだ（表 $1 ， 2$ ).

\section{考察}

第VII，第UII脳神経は共に脳幹より内耳道を経 由して末梢に分布するので，第UI脳神経の症状 が前面に出る Hunt 症候群や，逆に第叫脳神経 の症状が前面に出る聴神経腫瘍の場合に，近接 する第叫ないしは第И脳神経の症状を合併する ことは日常の臨床の場でしばしば経験する。一 万顔面痤攣は最初は眼瞼部特に下眼瞼に始まり 次第に煩部，口輪筋，頸部にも及ぶ不規則な反

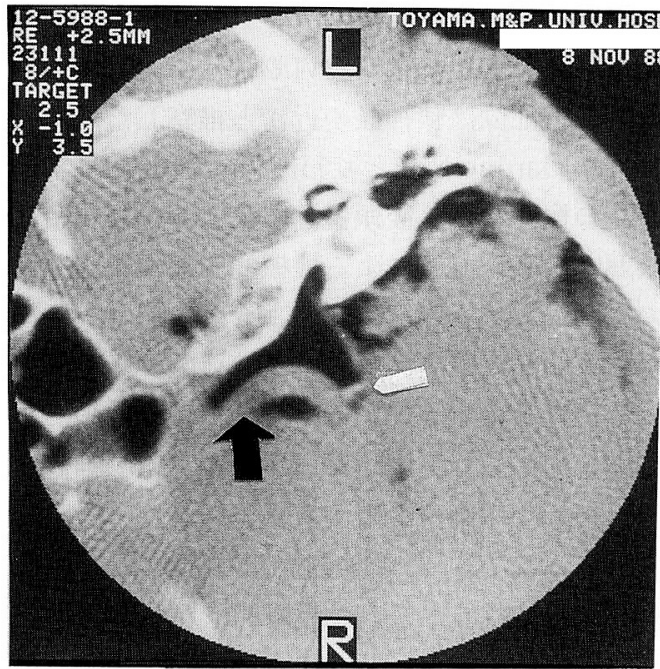

図 6 症例 7 72歳 男性) の左小脳橋 角部の air CT 所見, 大矢印は拡張, 蛇行 した椎骨動脈を，小矢印はPICA を示す。 復性不随意運動3) と定義される。

表 2 神経耳科異常所見と画像診断の異常

\begin{tabular}{|c|c|c|c|c|}
\hline 症 例 & 異常所見 & 画 像 診 断 & 血清脂質 & その他 \\
\hline 1 & $\begin{array}{l}\text { 兩側 ABR の異常 } \\
\text { 健側 CP }\end{array}$ & 椎骨動脈拡張 & $\uparrow$ & \\
\hline 2 & $\begin{array}{l}\text { FFS }(+) \\
\text { OKN 錯倒 } \\
\text { ETT SACCADIC }\end{array}$ & 正 常 & $\uparrow$ & \\
\hline 3 & 健側 CP & 未 検 & $\uparrow$ & \\
\hline 4 & ETT SACCADIC & 未 検 & 正 常 & \\
\hline $5:$ & ETT SACCADIC & AICA の蛇行 & 正 常 & \\
\hline $6:$ & 両側前庭機能低下 & 未 検 & 未 検 & \\
\hline $7:$ & $\begin{array}{l}\text { 健側 ABR 異常 } \\
\text { ETT ATAXIC }\end{array}$ & $\begin{array}{l}\text { 椎骨動脈拡張 } \\
\text { PICA? の } \\
\text { ROOT ENTRY ZONE } \\
\text { の接触 }\end{array}$ & 未 検 & \\
\hline $8:$ & OKN 抑制 & 正 常 & 正 常 & \\
\hline $9:$ & $\operatorname{FFS}(+)$ & 椎骨動脈拡張 & 正 常 & \\
\hline $10:$ & $\mathrm{OKN}$ 抑制 & 未 検 & 正 常 & 高血圧 \\
\hline $11:$ & 両側 ABR 異常 & 脳底動脈拡張, 蛇行 & 正 常 & \\
\hline
\end{tabular}

（注）画像診断：air CT, VAG. 血清脂質 : 総 cholesterol, TG 
病因については Harris5) らは degenerative neuritis のある一型が第叫脳神経に生じて拉り その障害部位は膝神経の近傍と推察した。

近年 Gardner ${ }^{6)}$ やとりわけ Jannetta らの手術 所見の検討から，後頭蓋窩の第VII脳神経起始部 に扣ける微小血管による機械的圧迫が顔面痙攣 の原因であるとみなされるようになってきた。 さらに顔面痤攣症例に於いて第UI脳神経を圧迫 している微小血管が，近接する第И脳神経にも 影響を与え，耳鳴，めまいなどの第刈脳神経症 状を来した症例の手術例も報告されている1).

一方, 深谷 ${ }^{2)}$ らの検討では顔面㾏攣症例に ABR を施行したが，中枢障害を示唆する所見 は全く得られなかった．これは第И脳神経と第 UII脳神経の transitional zone の違いにあると結 論している，第笑脳神経は，視神経を除いては もっとも長いグリア部分を持つ脳神経でその長 さは $5 \mathrm{~mm}$ から $11 \mathrm{~mm}$ とされ, transitional zone は内耳孔ちかくにある8) と言われている. すなわち第UII脳神経の glia-schwann 移行部は 第 $\mathrm{V}$, VII脳神経に比べて脳幹近くの root entry zone よりも末梢側にあるため第壮脳神経の NVCC (neurovascular cross compression) は内 耳孔付近で起こりらる. 反面, 第VI脳神経の transitional zone は脳幹近くの root entry zone にあるとされている。すなわち微小血管が transitional zone で神経の圧迫が顔面痤攣を起 こしていると仮定すると第壮脳神経の症状は起 こり得ないのである.しかし今回の検討では耳 鳴やめまいを訴光た症例がそれぞれ3，6例あ った。 また平衡機能検査で自発眼振や頭位眼振 が認められた症例や，顔面痤攣と同側（患側） の温度眼振の低下が認められた症例も2 例経験 した（表 1)。これらの症例では第VI脳神経血 管圧迫だけでなく第亚脳神経への血管圧迫も生 じている可能性は大きいと推察される.

ところで今回検討した顔面痤攣24例中実に11 例に第叫脳神経の起始部での圧迫が原因とは考 えられない脳幹症状を示す所見が得られた。こ のらち末梢の第叫脳神経が疑われたのは症例 3
と6のみであり，他の 9 例には中枢障害（特に 脳幹症状）を示唆する所見が得られた。これら の画像診断（表 2 ）を見てみると症例 $1 ， 7$, 9，11に見られるよらに微小血管の loop と言 らよりは椎骨動脈や脳底動脈の拡張, 蛇行とい ら明らかな血管障害が認められた。 小脳, 脳幹 扣よび内耳は椎骨または脳底動脈から血液の供 給を受けている．椎骨動脈からは後下小脳動脈 （PICA，小脳後下部に分布）が分岐し脳底動脈 からは前下小脳動脈（AICA，小脳の前下部に 分布), 迷路動脈 (内耳に分布), 橋枝, 上小脳 動脈 ${ }^{9)}$ が分岐している.この様に椎骨, 脳底動 脈の拡張や蛇行による圧迫が，これらの血管か ら分岐する微小血管(とりわ惰 P や AICA) に血行障害などの影響を与えるであろらことは 容易に推察される。たと艺ば前下小脳動脈循環 障害の症例では回転性めまいを訴光, 眼球運動 に障害が認められ，ETT で saccadic pursuit pattern 等が認められる10). 山崎11) らの第价脳 神経血管圧迫症候群の報告でも NVCC が内耳 道近傍の第UII脳神経圧迫部位の機能立進に AICA 領域の循環障害が加わった可能性も指摘 されている。また山本1)らの第UII, UII脳神経血 管圧迫合併例の報告でも滑動性眼球運動に異常 が認められ ETT で段階状の眼球運動が記録さ れ, 山本らはこれを自発眼振の superimpose と結論したが AICA の循環異常を原因に求め る方が納得ゆくと思われた。しかし福島 ${ }^{12)} ら$ が顔面痓攣1752例中，手術で確かめた圧迫血管 は, AICA 42\%,PICA 35\%,VA(椎骨動脈) 22 \%であり，AICA P PICA などの微小血管が その原因の汪とんどを占めていた，我々の 24 症 例の内手術例は 3 例と少ないので, 偶然に椎骨 動脈や脳底動脈の拡張, 蛇行例が多かったのか それとも画像診断上の問題なのかについては, さらに症例数を重祆て検討する必要があるもの と推察した.

また野末13) らの第UII脳神経血管圧迫症例に 対する手術報告にもあるよらに動脈硬化の進行 が関与している可能性もある，我々の症例では 
症例 1，2，3（表2）に血清脂質の高值を認 め, また症例10は高血圧の治療中であった。こ れらの症例の内, 症例 $1,2,10$ には中枢性と 思われる障害が認められた。すなわちこれらの 症例では, 動脈硬化や高血圧などの血行障害が 中枢性聴平衡障害の原因になっている可能性も 推察された.

顔面痙攣と類似疾患に Meige 症候群がある. これは tic や hemifacial spasm とは異なり, 両 側性で顔面正性中付近の筋, 特に眼輪筋にもっ とも強く起こる顔面痤攣の一種で, 薬理学的に 大脳基底核に扣ける dopamine, acetylcholine, GAVA の関与が推察され, 神経生理学的にも 眼輪筋にたいする大脳基底核からの異常興奮性 駆動の存在が指摘されている14)。症例 2 は Meige 症候群と顔面痤攣の合併例であり FFS $(+)$, 一側性 OKN 錯倒, ETT で認められた saccadic pursuit patternなどの所見は，血管圧 迫といらょりこれらの中枢障害に起因している ものと推察される.

以上の様に第UI脳神経への血管の圧迫が原因 と言われている顔面痤攣症例でroot entry zone での第UII脳神経血管圧迫が直接の原因とは考え られない聴覚, 平衡系の障害が多数例に認めら れた.

Moller ${ }^{15)}$ らの, 顔面神経核が spasm や synkinesis の原因部位であるとする報告もある よらに, 脳幹に存在する顔面神経核自体への圧 迫も顔面痙攣発症の重要な因子の一つとされて いる.この様に必ずしも root entry zone の血 管圧迫だけを顔面痤攣扣よび顔面痤攣に随伴し ている聴平衡障害の原因に求めるのは困難な様 である.ところで脳外科領域からは神経血管圧 迫症候群症例に対する術前検査として頭部単純 撮影と高解像 CT のみ施行し, CT で異常所見 がない限り脳血管撮影は不要であるとの報告 ${ }^{12)}$ も見られる. しかし類皮囊胞, 聴神経腫瘍, 䯣 膜腫, 脂肪腫などが手術中に発見された報 告1216) もみられた．この点今後めまい, 耳鳴, 難聴等の原因の一つとして，血管による神経の
圧迫も有り得ると推察されたが，めまいの症例 の多くは，血行改善剂や神経安定剂の服用で制 御可能であるため，どのような症例を第UII脳神 経血管圧迫症候群と診断しMVDを施行すべき かは今後の問題点である13) とする報告も見ら れた。

聴神経腫が疑われた68例の air CT を再検討 し 7 例に血管輪を確認した神崎の報告17) もあ る。また脳外科の手術には後遺症が必ずしもな いわけではないので18) 手術を患者に勧める際 の説明13)にも耳鼻科としては air CT は不可欠 と推定される.この点第VIたたは第UII脳神経血 管圧迫症候群および合併例 ${ }^{19)}$ を疑った場合に， 比較的侵襲が少ない画像診断と神経耳科学的精 查の必要性が推察された。

\section{まとめ}

顔面㾏攣症例に神経耳科学的検査を施行した ところ, 多くの症例に中枢性, 特に脳幹障害を 示唆する聴覚平衡障害が認められた。この原因 としては拡張蛇行した椎骨または脳底動脈の圧 迫による脳幹障害やさらに, 動脈硬化, 高血圧 等に起因する血行障害および中枢での神経伝達 物質の異常などが考えられた。

\section{参考文献}

1）山本一男, 山崎 勤, 井須豊彦, 他 : 脳血管圧 迫により耳鳴, めまい(動摇視), ついで顔面 痤攣をきたした症例. Equilibrium Res $43: 83$ $\sim 87,1984$.

2) 深谷 卓 : 顔面痤攣 (耳鼻咽喉科の立場から). JHONS $3: 105 \sim 108,1987$.

3）水越鉄理 : 平衡機能検査の情報処理化, めまい . 平衡障害の診断と治療 (水越鉄理著). 61 114頁, 現代医療社, 東京, 1988.

4）若杉文吉：顔面痙攣について。臨床麻酔 5 : 839 842, 1981 .

5) Harris $W$ and Wright $\mathrm{AD}$ : Treatment of clonic facial spasm. Lancet I : 657 661, 1932.

6) Gardner EJ and Sava GA : Hemifacial spasmA reversible pathophysiological state. J Neurosurg $19: 240 \sim 247,1962$.

7) Jannetta PJ, Abbasy M, Maroon JC, et al : 
Etiology and definitive microsurgical treatment of hemifacial spasm. Operative techniques and results in 47 patients. J Neurosurg 47 : 321 328, 1977.

8）安岡正蔵, 高倉公明, 深谷 卓: Neurovascular compression に上る耳鳴・眩昔・温度眼振 反応消失の症例. 脳神経 $35: 1097 \sim 1101,1983$.

9) 平沢 興, 岡本道男: 脈管学・神経学・解剖学 2 (森於菟, 平沢興, 小川鼎三他編). 337頁, 金原出版, 東京, 1976 .

10）田淵 哲，田中友二：前下小脳動脈循環障害の 臨床的検討. Equilibrium Res 46:172 278, 1987.

11）山崎 勤, 林 光夫, 林奈美江, 他 : 小脳橋角 部神経血管圧迫症候群により久ニェール病様症 状および良性発作性頭位胘最症を呈した 3 例. Equilibrim Res 46 : 260 266, 1987.

12）福島孝徳：顔面㾏攣の治療（脳神経外科の立場 から). JOHNS $3:$ 109 112, 1987.

13）野末道彦, 龍 浩志, 上村研一：めまい症例に 対する神経血管减圧手術の経験. Equilibrium Res $43: 299 \sim 302,1984$.
14）山下 滋, 若杉文吉 : 特発性眼瞼痤卛と神経ブ ロック療法. 臨床麻酔 8:852 856, 1984.

15) Moller AR and Jannetta PJ : On the origin of synkinesis in hemifacial spasm. J Neurosurg $61: 569 \sim 576,1984$

16）浜田慎二, 浅原広澄,福島孝徳：Microvascular Decompression 2600例の報告. Pain Clinic 8 : 66 72, 1987.

17）神崎 仁，志賀逸夫：内耳道内およびその付近 の血管輪 (VASCULAR LOOP) と第UIII神経症 状. 耳展 $29: 61 \sim 66,1986$.

18）南吉昇, 平田秀登: ジャネッタ手術後の聴力 障害について。耳鼻臨床 $13: 294 \sim 295,1986$.

19）安村佐都紀, 大橋直樹, 水越鉄理, 他 : 手術に より顔面痤攣・めまい・拍動性耳鳴の消失をき たした第 UIIIII神経圧迫症候群の 1 症例. 耳鼻臨 床補36：153 158, 1989.

別刷請求先 : 大橋直樹 盯930-01 富山市杉谷 2630 富山医科薬科大学医学部耳鼻咽喉科学教室) 